\title{
Nietzschejeva kritika objektivnosti in njena "orodja»
}

Ali je Nietzsche podal kritiko objektivnosti? Vprašanje je po svoje retorično, kar pa še ne pomeni, da je odgovor nanj enostaven. A najprej, kaj vse naj bi ta kritika objektivnosti zaobsegala? ${ }^{1}$

Če začnemo s tem: Nietzsche je nedvomno postavil pod vprašaj vse znane kriterije objektivnega spoznanja. Pozitivistično utemeljitev objektivnosti v dejstvih je napadel z znamenito tezo, da "ravno dejstev sploh ni, samo interpretacije so « ${ }^{2}$. Nič manj oster ni bil do pojmov univerzalnosti in nujnosti, ki v medsebojni povezavi tvorita kriterij objektivnega spoznanja pri Kantu in v osnovi tudi pri Heglu. Univerzalnosti je zoperstavil teorijo perspektivizma, ki jo je najverjetneje treba razumeti tudi kot njegov odgovor na vprašanje, s kakšno razlago sveta je sploh mogoče nadomestiti koncept objektivnosti, ki za sabo evidentno pušča ogromne vrzeli.

Glede nujnosti v mišljenju - ideje, da mišljenje samo po sebi lahko jamči za gotovost svojih spoznanj, če so ta spoznanja dojeta kot rezultat nujnih miselnih sklepov - pa je bilo Nietzschejevo stališče naslednje: če ga pojmujemo na način, da »ena misel povzroča drugo misel«, mišljenja kot takega sploh ni. Ideja, da med dvema mislima obstaja nekakšna nujna vez, da iz ene misli po nuji izvira druga misel, je zgolj slepilo, ki ga omogoča dejstvo, da smo z gledišča zavesti zaradi njihove bliskovitosti slepi za celo množico afektov, ki sodelujejo pri nastanku vsake posamezne misli. ${ }^{3}$

1 Prispevek je nastal v okviru znanstvenega projekta J6-9392 »Problem objektivnosti in fikcije v sodobni filozofiji in programa P6-0014 »Pogoji in problemi sodobne filozofije«, ki ju financira Javna agencija za raziskovalno dejavnost Republike Slovenije.

2 Friedrich Nietzsche, Volja do moči, prev. Janko Moder, Slovenska matica, Ljubljana 1991, str. 281.

3 »'Vzročnost' se nam izmika; sprejemati neposredno, vzročno povezavo med mislimi, kakor jo logika - je posledica najbolj grobega in okornega opazovanja. Med dvema mislima imajo svoje igre še vsi mogoči afekti: vendar so gibanja prehitra, zato jih spregledamo, zanikamo...«Ibid., str. 278.

* Znanstvenoraziskovalni center Slovenske akademije znanosti in umetnosti, Filozofski inštitut 
Še bolj direktno kakor zoper kriterije objektivnega spoznanja, s katerimi Nietzschejeva filozofija stoji v morda celo spontanem nesoglasju -, pa je Nietzsche nastopal proti sami težnji po objektivnosti v sodobni filozofiji, ki je po njegovem v nekem bistvenem pomenu zlagana tendenca: »Mi nismo misleče žabe, objektivne in registrirane naprave s hladno uravnanim drobovjem, " pravi Nietzsche o filozofih in doda: „venomer moramo misli rojevati iz bolečine in jim materinsko dodajati vse, kar imamo v sebi krvi, srca, ognja, slasti, strasti, muk, vesti, usode, pogube. $\aleph^{4}$ Filozof po Nietzschejevem mnenju nikdar zares ne stremi po objektivnosti, pa naj je o tem še tako prepričan; njegovi pravi cilji so drugje, predvsem pa naj bi bili ti cilji bistveno višji. Objektivnost je, kot pravi, v najboljšem primeru »orodje filozofskega delavca«, ki ga bo moral filozof prihodnosti znati pustiti za seboj.

A tudi težnja po objektivnosti v sodobni filozofiji je za Nietzscheja v resnici epifenomen, odmev nekega globljega, filozofiji tako rekoč istoizvornega procesa, ki je - po številnih preobratih, in na koncu še v navezi z demokratično ideologijo in naraščanjem pomena znanosti - privedel do tega, da je filozof izgubil svoje pravo mesto, ki ga je, niti ne toliko po lastni krivdi, zavzel »objektivni človek«. Prav to potekajoče razvrednotenje filozofije v korist znanstvene objektivnosti je najverjetneje treba razumeti kot središče tarče, na katero meri Nietzschejeva kritika objektivnosti; na tem mestu hoče ta kritika doseči nek učinek, izpeljati nekakšno novo ovrednotenje, postaviti nov »red stopenj«, in znotraj te nove Rangordnung povrniti filozofiji njeno pravo vrednost.

Čemu se torej sploh spraševati po tem, ali je Nietzsche razvil kritiko objektivnosti? Najosnovnejši odgovor izvira iz nekega znanega, a vseeno po svoje precej presenetljivega podatka: Nietzsche ni cenil kritike, še zlasti ne filozofij, ki svoje osrednje poslanstvo vidijo v kritikah tega ali onega tipa. Kritika je za Nietzscheja proces, ki je po svojem bistvu obsojen na to, da v vseh ozirih obstane na polovici poti. $\mathrm{V}$ primeru filozofskih kritik to med drugim pomeni, da filozofija, ki se dojema kot kritika, na čuden način obtiči celo pred lastnimi vrati. Lep primer tega, o čemer govorim, predstavlja eno od stališč, ki jih je Nietzsche zavzel do spoznavne teorije, kritike spoznanja:

4 Friedrich Nietzsche, Vesela znanost, prev. Janko Moder, Slovenska matica, Ljubljana 2005, str. 12-13. 
Filozofija, skrčena na »spoznavno teorijo«, je v resnici samo še boječa epohistika in vzdržništvo: filozofija, ki ne more niti čez prag in si mučno krati pravico do vstopa - to je filozofija v zadnjih zdihljajih, konec, agonija, nekaj, kar zbuja sočutje. ${ }^{5}$

Filozofija, ki je skrčena na spoznavno teorijo, kritično utemeljevanje pogojev spoznanja, je torej po Nietzscheju obsojena na to, da se bo, dokler ne izdihne, odvijala na svojem zunanjem robu, in to Nietzschejevo prepričanje je treba raztegniti čez celotno kritično dimenzijo filozofije. Seveda ta načelna zadržanost do kritike njemu samemu več kot očitno ni preprečevala, da ne bi kritiziral ... rajši se vprašajmo, česa ne? Čemur bi dodal še to, da je bil Nietzsche, vsaj za moje pojme, tudi eden najbolj pretanjenih spoznavnih teoretikov - morda edini, ki je v enem samem kratkem vrinjenem stavku uspel strniti pomen besede razumeti. Toda vse to ne spremeni dejstva, da je Nietzsche - povsem enako kakor za objektivnost, in tudi z zelo podobnimi besedami kakor za objektivnost - tudi za kritiko dejal, da je zgolj »orodje«, ki ga bo filozofija prihodnosti morala znati občutiti globoko pod seboj:

Ti filozofi prihodnosti bodo zahtevali kritično disciplino in vsakršno privajenost, ki pripomore k snažnosti in strogosti v duhovnih stvareh, ne samo od sebe: sami jo bodo smeli javno nositi kakor nekakšen okras - kljub temu pa se zato še ne marajo imenovati kritiki. Ne dozdeva se jim majhna sramota, kakršne je deležna filozofija, če kdo dekretira, kar se danes tako rado dogaja: »Filozofija sama je kritika in kritična znanost - in čisto nič zunaj tega!« Tudi če je tako vrednotenje filozofije deležno ploskanja vseh francoskih in nemških pozitivistov (- mogoče bi bilo po volji celo Kantovemu srcu in okusu: spomnimo se samo naslovov njegovih poglavitnih del -): naši novi filozofi bodo kljub temu rekli: Kritiki so orodja filozofa, in ravno zato, kot orodja, še malo ne sami filozofi! ${ }^{6}$

Kritiki so torej samo »orodja filozofa, in ravno zato, kot orodja, še malo ne sami filozofi«. Za primerjavo: samo nekaj strani pred tem, v okviru istega poglavja Onstran dobrega in zla, ki nosi naslov »Mi učenjaki« in predstavlja Nietzsche-

Friedrich Nietzsche, Onstran dobrega in zla, prev. Janko Moder, Slovenska matica, Ljubljana 1988 , str. 109.

6 Ibid., str. 120. 
jev načeloma najbolj zgoščen in sistematičen poskus kritičnega ovrednotenja objektivnosti, Nietzsche o »objektivnem človeku« zapiše naslednje:

Objektivni človek je orodje, dragocena, lahko ranljiva in skaljiva merilna priprava in ogledalna umetnina, ki jo je treba varovati in spoštovati; ni pa cilj, ni izhod in vzhod, ni komplementarni človek, v katerem se upravičuje preostalo bivanje, ni konec - in še manj je začetek, porod in prvi vzrok, nič surovega, mogočnega, nase postavljenega, kar hoče biti gospodar [...].7

Tudi »objektivni človek« - učenjak, znanstvenik, ali filozof, ki v objektivnosti vidi najvišjo vrednoto spoznanja - je zgolj »orodje«, in čeprav je to orodje dragocena »merilna priprava in ogledalna umetnina, ki jo je treba varovati in spoštovati«, tudi »objektivni človek«, pravi Nietzsche, »sodi v roko močnejšega «" Vzporednica, ki jo Nietzschejev tekst potegne med vlogo kritike in vlogo objektivnosti, je očitna, in v resnici se moramo vprašati kvečjemu to, ali nas ta primerjava sploh sme čuditi. Nobenega dvoma namreč ni, da se, vsaj od Kanta naprej, kritika in objektivnosti vrtita okoli skupne osi. Pravzaprav si sploh ni mogoče predstavljati filozofske kritike, ki ne bi stremela k idealu objektivnosti. Kritika, ki razglaša da govori $\mathrm{v}$ imenu resnice, ki torej daje vedeti da resnico pozna, je bolj kot ne postala le še domena obskurantistov, fanatikov in stvar slabega okusa: objektivnost je vodilo, kriterij, cilj, pogoj in metoda kritike. A odvisnost seveda ni le enostranska: tisto, kar sploh odpira dimenzijo objektivnega spoznanja, je v vseh ozirih ravno kritično mišljenje. Zgolj kritično mišljenje ima v sebi potencial, da lahko poda utemeljitev kriterijev objektivnega spoznanja; zgolj kritično mišljenje se je zmožno v kateri koli konkretni situaciji dokopati do objektivnega vpogleda v jedro problema. Če je torej, po eni strani, objektivnost najvišja vrednota kritike, potem je, po drugi strani, kritično mišljenje treba prepoznati kot edino možno pot, ki vodi do objektivnih spoznanj.

Kritika in objektivnost sta torej prepleteni na vse možne načine, inklinirata druga k drugi, in s tega vidika ni torej niti najmanj presenetljivo, da ju tudi Nietzsche obravnava v skupni povezavi. Seveda pa se - ko enkrat seštejemo Nietzschejevo odklonilno stališče do kritike, zlasti če je ta dojeta kot ciljni domet filozofskega delovanja, in dejstvo, da sta kritika in objektivnost tako rekoč nerazločljivo po-

\footnotetext{
7 Ibid., str. 113.

8 Ibid., str. 112.
} 
vezani - celoten problem pokaže v povsem drugačni luči. Pravzaprav bi moral dejati, da šele s to povezavo sestopimo k pravemu začetku.

Prvo vprašanje, ki se s tem v zvezi zastavi, je namreč prav to: ali je Nietzschejevo obravnavo problema objektivnosti res mogoče adekvatno opredeliti kot kritiko? Kritika in objektivnost sta za Nietzscheja dva obraza iste težnje, katerih se je mogoče znebiti le tako rekoč v istem paketu. In najmanj, kar je pri tem jasno, je, da se vsaj kritike ne bo mogoče znebiti s kritiko. Lahko sicer kritično razpravljamo o kritiki, a na ta način nikoli ne bomo dosegli tega, kar Nietzsche pričakuje od filozofa prihodnosti, namreč da bo kritiko smel občutiti "globoko pod sabo in za seboj«. »Kritika kritike« sicer lahko poteka, ne more pa se dovršiti: med njen potek in cilj, ki naj bi ga dosegla, se umešča neka pregrada, ki jo v resnici predstavlja njeno lastno prazno kopičenje. Do zastavljenega cilja očitno vodi povsem druga pot, ki se kritiki v širokem loku izogne: filozof prihodnosti bo na kritiko lahko gledal zviška šele takrat, ko bo sam postal tista skrivnostna figura, ki ji Nietzsche pravi ustvarjalec novih vrednot. Takrat bo kritična težnja skupaj s polovičništvom, ki jo kritika prinaša s seboj, presežena - vendar ne kot rezultat nekega kritičnega procesa, temveč zato, ker bo bodisi preprosto odmrla bodisi postala vključena $\mathrm{v}$ to višjo formo filozofskega delovanja.

Kritika objektivnosti seveda ni v povsem enakem položaju: že na začetku smo videli, da vsebuje dovolj konkretnih poudarkov - še zlasti je tu pomembno, da teorija perspektivizma, po Nietzscheju, lahko nadomesti univerzum objektivnosti -, da ni mogoče zanikati, da ta kritika v nekem splošnem pomenu poteka $\mathrm{v}$ smeri svoje dovršitve. Vprašanje, ki se v zvezi z njo v resnici zastavlja, je prej: ali so vsi ti kritični poudarki zares rezultat kritike $v$ strogem pomenu besede, ali pa jih omogoča nek drug tip filozofske operacije, ki je kritiki zunanja in ki morda celo poteka po neki povsem drugačni poti od nje? In dejansko bomo videli, da je $\mathrm{v}$ tem oziru potreben kompromis: kar v posplošenem smislu imenujemo »kritika objektivnosti«, vključuje tako elemente kritike, kakor tudi genealogije, perspektivične ontologije in še zlasti neke znotrajfilozofske politike. Skratka, »kritika objektivnosti« je v prvi vrsti ime za nek širši dispozitiv pristopov.

Vendar pa to še ne pomeni, da kritike objektivnosti v ožjem, strogem pomenu neke filozofske kritike sploh ni. Celo nasprotno, kritika objektivnosti v strogem smislu, predstavlja verjetno celo paradigmatski primer Nietzschejeve lastne kritične metode, ki se že na operativni ravni v nekem bistvenem pogledu razlikuje 
od tipa kritike, s pomočjo katere spoznavni teoretiki iščejo pogoje objektivnega spoznanja. Skratka, kritika objektivnosti v ožjem smislu je sicer del nekega širšega dispozitiva, vseeno pa že sama po sebi ponuja neko ključno distinkcijo v razmerju do tistega, kar kritizira.

V čem se torej kaže njen osrednji problem? Zakaj se kritika objektivnosti v ožjem, epistemološkem smislu zdi nemožna? Stvar je več kot očitna:

Ker je objektivnost univerzalni pogoj kritike, to nujno lahko pomeni le eno - s tem ko kritika postavi pod vprašaj kategorijo objektivnosti, v resnici pod vprašaj postavi tudi samo sebe. Bolj enostavno: kritika objektivnosti je proces, ki samega sebe postavlja pod vprašaj; ne more potekati drugače, kakor da se postavlja pod vprašaj. Ujeta je v zanko, ki jo Nietzsche v nekaterih drugih podobnih primerih imenuje Gegenbewegung, protigibanje - ki v tem primeru označuje dejstvo, da kritika objektivnosti z vsakim novim spoznanjem ruši pogoje svoje možnosti, deluje proti sebi. In seveda tudi obratno: medtem ko poteka, uteleša objekt svoje kritike in tako znova deluje proti sebi.

To protigibanje, ki napada samo gledišče kritike, je v vsakem primeru ključno. Nedvomno namreč lahko rečemo, da ta Gegenbewegung, napad na gledišče kritike, ni samo specifična notranja prepreka kritike objektivnosti, ampak je, kot je nakazal že Heidegger, v tem protigibanju treba videti eno bistvenih potez Nietzschejeve filozofije nasploh. Kar seveda še ne pomeni, da »rešitev« tudi že odpravlja problem.

Mislim, da je to ključno specifiko Nietzschejeve filozofije, prek katere se med drugim že nakaže tudi eden od vidikov teorije perspektivizma, mogoče strniti v povezavi dveh znanih Nietzschejevih argumentov, uperjenih proti teoretikom objektivnega spoznanja.

Prvi argument poda Nietzschejevo splošno stališče do filozofskega iskanja temeljev gotovosti:

Utegnilo bi se zdeti, da sem se izognil vprašanju o "gotovosti«. Res je nasprotno: ampak medtem ko sem spraševal po kriteriju gotovosti, sem preizkušal, po katerem težišču so do zdaj sploh tehtali - in da je vprašanje stopnje gotovosti že samo odvisno, vprašanje druge stopnje. 
Vprašanje vrednot je bolj fundamentalno kakor vprašanje gotovosti: to drugo postane resno šele s predpostavko, da imamo odgovor na vprašanje vrednot. ${ }^{9}$

Najsplošnejši problem filozofskega iskanja temeljev gotovosti, kamor nedvomno sodi tudi težnja po utemeljitvi objektivnega spoznanja, je po Nietzscheju torej v tem, da je »vprašanje stopnje gotovosti že samo odvisno, vprašanje druge stopnje«. Bolj temeljno kakor samo vprašanje gotovosti, je vprašanje vrednot, pri čemer pa Nietzsche očitno ne meri le na nekakšno abstraktno večjo vrednost tega vprašanja, ampak nasprotno: njegova teza je, da je vprašanje gotovosti že samo $v$ sebi odvisno od razrešitve vprašanja vrednot. Ključen doprinos k razumevanju te teze nedvomno predstavlja Heideggerjeva ugotovitev, da je za Nietzscheja »bistvo vrednote v tem, da je gledišče «10. To namreč pomeni, da je za Nietzscheja osnovni problem vprašanja gotovosti prav nerazrešeno vprašanje gledišča.

Preidimo zato neposredno še k drugemu argumentu. Ta je zelo razvidno uperjen proti konkretni, Kantovi transcendentalni utemeljitvi objektivnega spoznanja:

S tem, da svetu, dostopnemu našim organom, prisodimo tudi odvisnost od njih, $\mathrm{s}$ tem, da imamo svet za subjektivno pogojen, s tem še ni rečeno, da je objektivni svet sploh mogoč. Kdo nas sili misliti, da je subjektiviteta realna, bistvena? ${ }^{11}$

Nietzschejev argument proti transcendentalni utemeljitvi objektivnosti torej v prvi plan ne postavlja pojma objekta, pač pa pojem subjekta. In dejansko lahko rečemo, da je za celoten Nietzschejev pristop k spoznavni teoriji značilno prepričanje, da je končni recipient spoznanja - tisti, ki mu je spoznanje posredovano; tisti, ki naj bi na koncu nekaj razumel - vsaj tako problematičen kakor objekt.

9 Nietzsche, Volja do moči, str. 341.

${ }_{10}$ »Bistvo vrednote je $\mathrm{v}$ tem, da je gledišče. [...] $\mathrm{Z}$ označenjem vrednote za gledišče pride za Nietzscheja do nečesa in za Nietzschejev pojem vrednote bistvenega: kot gledišče jo vsakokrat postavlja gledanje, postavljena je zanj. To gledanje je táko, da vidi, kolikor je [že] videlo; da je videlo, s tem ko si je to ugledano [das Gesichtete] kot tako pred-stavilo, in ga takó postavilo. Šele prek predstavljajočega postavljanja postane točka, ki je nujna za računanje na nekaj, in na ta način vodi linijo pogleda tega gledanja, gledišče, kar pomeni, da postane to, za kar v gledanju in vsem delovanju, gre. Vrednote torej niso [že] pred tem nekaj na sebi, tako da bi jih kasneje lahko ob priliki jemali kot gledišča. « Martin Heidegger, »Nietzschejeve besede Bog je mrtev«, Phainomena 31-32: Nihilizem, prev. Aleš Košar, Nova revija, Ljubljana 2000, str. 157.

11 Nietzsche, Volja do moči, str. 331. 
Pierre Klossowski je izvrstno pokazal, da je za Nietzscheja zavest, gledano v celoti, nekakšen proces cerebralne samoprevare, ki deluje tako, da nezavedne impulze iz katerih nastajajo misli, projicira navznoter, v »središče zavesti«, kar nam omogoča, da sami sebe - pod pogojem uspešnega delovanja te samoprevare - doživljamo kot »misleči jaz« ${ }^{12}$ »Misleči jaz« - subjekt »mišljenja «s sedežem v zavesti - je torej zgolj in izključno nekakšna odvisna spremenljivka. Oziroma drugače: ker je "subjekt mišljenja« pogojen s kontingentnim delovanjem cerebralne samoprevare, je jasno, da na njem ni ničesar univerzalnega ali nujnega. Vendar pa v tem še ni jedro Nietzschejevega argumenta, vzetega v celoti. Za Nietzscheja je morda še bolj kakor sam poudarek, da je subjekt mišljenja efekt prevare, pomembno pravilno ovrednotenje te prevare. Treba je dojeti, da ta prevara opravlja neko funkcijo, ki je $z$ vidika življenja tisočkrat dragocenejša od kateregakoli spoznanja: nobenega dvoma namreč ni, da je učinek te cerebralne samoprevare, ki zavest postavlja v center telesa in »mišljenje« v center zavesti, treba šteti med najbolj bistvene pogoje preživetja človeške vrste.

Ta nova postavitev reda stopenj med spoznanjem in višjo vrednostjo prevare je bistvena tudi, in še zlasti, s spoznavnoteoretskega vidika. $\mathrm{V}$ resnici se namreč šele $s$ tem prevrednotenjem razmerja med prevaro in spoznanjem sproži glavno vprašanje Nietzschejevega pristopa k spoznavni teoriji, in sicer vprašanje polivalentne funkcije vsega tistega, kar smo vajeni enoznačno pojmovati kot »spoznavni aparat subjekta«.

Nietzsche pravi, da "naš spoznavni aparat sploh ni naravnan na spoznanje «13. In dejansko se je treba vprašati: če je cerebralna samoprevara, ki ustoliči »subjekt mišljenja«, bistveni pogoj preživetja človeške vrste - ali ni potemtakem celo bolj verjetno, da je to, kar smo vajeni dojemati kot »spoznavni aparat«, v prvi vrsti prilagojeno prav nalogi ohranjanja te temeljne, a ranljive iluzije? Za Nietzscheja je spoznavanje kvečjemu ena od enostavnejših funkcij »spoznavnega aparata«, njegova glavna naloga je neskončno kompleksnejše permanentno ohranjanje centralne iluzije, ki v danih okoliščinah predstavlja pogoj preživetja vrste. To pa pomeni tudi, da je mikro-evolucija zavesti, ki jo Nietzsche opisuje na

${ }_{12}$ Prim., Pierre Klossowski, Nietzsche and the vicious circle, Continuum, London 1997, str. $18-27$.

13 Nietzsche, Volja do moči, str. 287. 
več mestih, ${ }^{14}$ naš »spoznavni aparat « morala prilagoditi nalogam, ki so v vseh pogledih nasprotne od tistih, ki jih pripisujemo spoznanju. "Spoznavni aparat« je v veliko večji meri kakor spoznanju mikro-evolucijsko prilagojen ohranjanju "subjekta spoznanja«, ki mu mora tako rekoč servirati vse tisto, s čimer lahko hrani svojo notranjo iluzijo. In seveda tudi obratno: vse tisto, kar »subjekt spoznanja « dojema kot najbolj neizpodbitna dejstva zavesti - denimo »dejstvo« njene intencionalne naravnanosti na objekt -, so v resnici še najverjetneje nekakšne prilagoditve, ki mu v spregi s cerebralno samoprevaro in zgradbo govorice omogočajo ohranjati tisto slepilo, ki je on sam.

Prava tarča Nietzschejeve kritike transcendentalne utemeljitve objektivnega spoznanja torej ni transcendentalni subjekt, ki je v svojem delovanju, kot pogoj izkustva, izvzet vsakemu izkustvu. Glavna tarča Nietzschejevega napada je tisto najelementarnejše notranje dejstvo zavesti, ki predstavlja samo izhodišče Kantovega transcendentalnega projekta, še preden se ta sploh začne: notranje dejstvo, da se za zavest pojavljajo objekti. Kantova utemeljitev objektivnega spoznanja, je, kakorkoli že obrnemo, samo nekakšno pojasnilo tega notranjega dejstva. Toda z Nietzschejevega vidika je to »dejstvo « izključno ena od form prilagoditve zavesti njenemu najkompleksnejšemu cilju, vzdrževanju iluzije subjekta. Intencionalnost zavesti je dejstvo kvečjemu v zgradbi neke iluzije.

Zgoraj navedeni Nietzschejev argument proti transcendentalni kritični utemeljitvi objektivnega spoznanja je torej mogoče reformulirati na naslednji način: transcendentalna kritika sicer pravilno izpostavi, da je »objektivni svet« šele rezultat subjektivne konstitucije realnosti, pri čemer pa ostaja slepa za to, da je sámo dejstvo, da se zavesti pojavljajo objekti, zgolj notranji člen objektivne prevare, ki konstituira subjekt.

Od tod se lahko vrnemo h glavnima vprašanjema. Najprej k vprašanju Nietzschejeve teze, da je problem gotovosti že sam na sebi, na svojem lastnem terenu, odvisen od problema vrednot.

Primer, ki smo ga pravkar obravnavali, je z vidika Nietzschejeve kritike objektivnosti pomemben zlasti iz naslednjega razloga: $v$ njem je mogoče videti neka-

14 Denimo: »Zavest: $\mathrm{v}$ začetku najdlje stran od biološkega centra individua, vendar proces, ki se poglablja, ponotranja, stanovitno bliža centru. «Ibid., str. 289. 
kšen prikaz, da gola sprememba vrednostnega gledišča - konkretno, nov akcent na vitalni funkciji prevare - dejansko lahko v esencialnem pomenu sprevrne tudi same kriterije gotovosti. To je po Nietzscheju mogoče razlagati na en sam način: namreč, da so vsi kriteriji gotovosti, na tak ali drugačen način, odvisni od tistih vrednostnih gledišč, za katera so bili postavljeni. V tem je vsebovana osnovna zamisel teorije perspektivizma.

Odpor, ki ga ta teza proizvaja, izvira od tod, da smo kriterije gotovosti privajeni razumeti kot domeno čistega mišljenja. Toda kakšen status sploh pritiče »čistemu mišljenju « v razmerju do polivalentne funkcije spoznavnega aparata, se pravi, v okviru razlage, da so - še najmanj čutila, zato pa velik del delovanja cerebralnega sistema in zgradba govorice - mikro-evolucijsko prilagojeni ohranjanju iluzije subjekta, ki predstavlja kontingentni pogoj preživetja vrste?

Povsem jasno je, da mišljenje v tem procesu vzdrževanja iluzije ni zgolj nekaj, kar bi bilo prevarano: še preden bi mišljenje sploh lahko bilo prevarano, je, kot prvo, razvojno gledano, več kot očitno moralo nastati iz te iste prevare, ki naj bi ga slepila. V svoji razviti obliki, pa je nedvomno prav mišljenje tisti šiv, ki delovanje možganov in govorico veže skupaj in ju koordinira v skupno oporo vzdrževanju centralne iluzije subjekta. To je po Nietzscheju funkcija čistega uma: koordinacija dveh polov vitalne iluzije. In zato ni niti najmanj presenetljivo, da so vse moderne oblike racionalizma, od Descartesa do Hegla, najvišjo stopnjo gotovosti odkrile prav v tej iluziji sami, neovrgljivosti samozavedanja mislečega subjekta. A tudi v tem, po Nietzscheju, ne smemo videti tega, da je mišljenje postalo talec lastne iluzije, prej obratno: čisto mišljenje $\mathrm{v}$ tem pogledu ravno izpolnjuje svojo bistvo, diktira pogoje ohranitve, vrednoti.

Presenetljivo, skoraj ironično je, da je najekstremnejšo verzijo teorije perspektivizma mogoče opisati prav kot absolutno univerzalizacijo tako dojetega delovanja »čistega uma«. Heidegger je to teorijo povzel z naslednjimi besedami:

Vse bivajoče je zato, ker se v bistvenem odvija kot volja do moči, "perspektivično«. Je »perspektivizem« (se pravi, konstitucija bivajočega kot presojajočega gledanja, ki postavlja gledišča), na način, da vsak center moči - in ne samo človek - 
konstruira celoto preostalega sveta iz samega sebe; se pravi, meri, se dotika in oblikuje, v sorazmerju $\mathrm{z}$ lastno močjo. ${ }^{15}$

Perspektivizem ukinja razliko med »resničnim« in »navideznim« svetom iz razloga, ker v skladu s to teorijo vsi centri moči, vsa možna gledišča sokonstituirajo preostanek sveta na način, da vanj projicirajo pogoje svoje lastne ohranitve: nobena od teh projekcij ni bolj resnična, ali bolj lažna; razmerja med njimi je mogoče meriti le po stopnjah moči. Delovanje mišljenja je v tem oziru samo posamičen primer te splošnejše ontološke sheme.

Vendar pa teorija perspektivizma ponuja samo abstrakten, nazorski odgovor na vprašanje razlike med Nietzschejem in teoretiki objektivnega spoznanja. Tudi sicer bi dejal, da ima perspektivizem to »slabo« lastnost, da ga, če ga motrimo izolirano - podobno kot to velja tudi za sam pojem volje do moči -, spontano zanaša v smer abstraktnosti, kar je seveda v popolnem nasprotju s tem, kar je Nietzsche hotel doseči z obema konceptoma, ki naj bi v zadnji instanci opisovala notranjo divergentnost življenja. A v čem se torej razlika med Nietzschejem in teoretiki objektivnosti pokaže na konkretnejši, tako rekoč metodološki ravni?

Ker je naloga mišljenja v njegovi najčistejši formi v tem, da od znotraj povezuje vitalno iluzijo, in ker je mišljenje po svojem bistvu "pristransko« vrednotenje, je za Nietzscheja vsak poskus, da bi mišljenje »očistili« iluzij, oziroma da bi na podlagi kritičnega pretresa izoblikovali gledišče, ki bi jamčilo za gotovost spoznanja, nesmiseln. V tem oziru dejansko obstajajo samo različne interpretacije, ki pa, kljub vsemu, lahko vsebujejo visoke stopnje verjetnosti. Ključ do te večje verjetnosti? Nietzschejevo odkritje polivalentnosti spoznavnega aparata, ki mu tu sledimo kot vzorcu Nietzschejeve metode, se dejansko umešča v nekakšno Gegenbewegung mišljenja v razmerju do njegovega bistva: tam, kjer v ontološkem kontekstu nekaj mislimo z neovrgljivo gotovostjo, torej tam, kjer nas mišljenje prišije na pogoje iluzije, je treba stopiti vstran in v nekakšnem protiritmu tvegati $\mathrm{z}$ nasprotno interpretacijo. Bivajoče in postajanje, zavestno in nezavedno, zavest in telo, nasprotovanje atomizmu, nasprotovanje pojmu praznine, nasprotovanje samozavedanju, nasprotovanje »nasprotjem « - to je le nekaj primerov Nietzschejeve rabe te metode, ki narekuje, da - kadarkoli v ontološkem kontekstu

15 Martin Heidegger, Nietzsche Volume III: The Will to Power as Knowledge and as Metaphysics, Harper and Row, San Francisco 1987, str. 199. 
nastopi nekaj, česar ne moremo ne misliti - v tem, kar mišljenje postavlja kot nujno, prepoznamo pogoj notranje iluzije.

Pričakovali bi, da napad na filozofske utemeljitve objektivnega spoznanja predstavlja samo jedro Nietzschejeve kritike objektivnosti, ali pa vsaj njeno osnovno izhodišče. A v resnici je v glavnih besedilih, v katerih Nietzsche izrecno problematizira vprašanje objektivnosti, tema kritike filozofskih utemeljitev objektivnosti skoraj v celoti odsotna - česar nikakor ni mogoče pojasniti s kronološkim zaporedjem razvoja Nietzschejeve filozofije, saj sta obe temi, z večjimi ali manjšimi poudarki, ločeno prisotni v vseh večjih Nietzschejevih zrelih delih.

Problem, ki se ga Nietzsche loteva v svojih najbolj zgoščenih razpravah o objektivnosti, kakršni sta »Mi učenjaki« ter »O brezmadežnem spoznanju«, ni epistemološki problem kriterijev gotovosti, temveč problem nastajanja nekakšnega monopola nad resnico. Ta monopol nad resnico - dodajmo, da resnici sami ne prinaša nič dobrega ${ }^{16}$ - si je pod skupnim označevalcem »objektivnost « prisvojila himera sestavljena iz metode, vrednote in nekega posebnega človeškega tipa. Za metodo, ki predstavlja prvi del himerinega telesa, Nietzsche uporablja izraz »brezinteresno spoznanje«, ki mu prvenstveno služi kot oznaka za znanstveno objektivnost. Vrednota je objektivnost, vendar ne več vzeta samo kot ideal znanstvenega pristopa, temveč tudi, in še zlasti, kot tip vrednote, ki do potankosti ustreza merilom sodobne demokratične morale. Tip človeka, ki predstavlja tretji, prav tako nepogrešljivi del himerinega telesa, pa je že večkrat omenjeni »objektivni človek«, za katerega ima Nietzsche v svojem besednjaku sicer na zalogi še celo plejado drugačnih poimenovanj, ki jih, vsaj na prvi pogled, ni najenostavneje smiselno povezati med seboj: »objektivni človek« je tako tudi (lažno) »breja luna«, ki se po zemlji plazi »z zahrbtnimi mačjimi koraki«, »moški brez ostrog«, »ogledalo s sto očmi«, »pohotni menih«, »dragocena zrcalna umetnina«, ali pa celo kar »suženj«.

${ }_{16}$ Tematike tega omejujočega učinka na resnico, se v delu Ostroge, Nietzschejevi stili, na zelo svojstven način loteva tudi Derrida: Jacques Derrida, Ostroge. Nietzschejevi stili, prev. Jana Pavlič, Hyperion, Koper 2010, str. 56-59. 
Vloga »objektivnega človeka« je bistvena iz dveh razlogov. Kot prvo, »objektivni človek« je tisto, kar bi lahko poimenovali subjektivni pogoj razvoja znanstvene objektivnosti. »Objektivni človek« je tista specifična in edinstvena oblika bivanja, znotraj katere se je zaradi njenih docela subjektivnih predispozicij in specifik sploh lahko razvila in udejanjila težnja po znanstveni objektivnosti: »Objektivni človek [... je] idealni učenjak, v katerem je znanstveni nagon, potem ko je tisočkrat v celoti ali na pol odpovedal, enkrat le zacvetel in se razcvetel ${ }^{17}{ }^{17}$ Nietzsche je bil namreč prepričan, da se sam ideal »brezinteresnega spoznanja«, sploh pa volja, disciplina in odrekanje, ki so potrebni za njegovo udejanjanje, nikoli ne bi mogli razviti in uveljaviti do zadostne mere, če se ta ideal ne bi tudi sam napajal in izraščal iz neke specifične patologije, ki jo je »objektivni človek« v skoraj že izoblikovani obliki podedoval od »religioznega človeka«. To patologijo, ki jo je hkrati treba motriti tudi kot režim moči in specifično zgradbo ekonomije užitka, je Nietzsche kasneje, v H genealogiji morale poimenoval »asketski ideal «. ${ }^{18}$

Ideala »brezinteresnega spoznanja - ki zato da bi bil udejanjen, od nas zahteva iskanje načinov, kako preseči raven subjektivno pogojenih ali motiviranih stališč; odkritje načina, kako na reči gledati z neobremenjenega, nevtralnega gledišča in jih posledično videti »takšne, kot so«, skratka, odkritje načina, kako odšteti sebe iz svojega gledišča - se torej, po Nietzscheju, že v izhodišču drži neka plast zlaganosti, ponarejenosti, in ta ponarejenost ni zgolj površinska. $\mathrm{V}$ primeru ideala »brezinteresnega spoznanja« ne gre preprosto zato, da bi se nek preostanek subjektivne patologije skrival izza ideala, nasprotno: ideal sam, se pravi, imperativ preseganja subjektivnih patologij, je že sam po sebi forma najekstremnejše možne subjektivne patologije, ki se na nek način napaja iz zanikanja svoje resnične (patološke) biti.

Če je na samem idealu, ki se razrašča iz zanikanja svoje resnične narave, nekaj zlaganega, ponarejenega, pa je na človeškem tipu, ki iz zanikanja svojih dejanskih vzgibov ustvari svoj najvišji ideal, dejansko nekaj perverznega. Od tod lahko vsaj deloma pojasnimo zelo slikovit nagovor »objektivnih ljudi«, kakršnega Zaratustra poda v razdelku »0 brezmadežnem spoznanju«:

$17 \quad$ Nietzsche, Onstran dobrega in zla, str. 112.

18 Za eno najprodornejših analiz ekonomije asketskega ideala glej: Alenka Zupančič, »Asketski ideal«, Filozofski vestnik XX (1/1999), str. 57-72. 
K zaničevanju zemeljskega so vam pregovorili duha, ne pa drobovja: to pa je najmočnejše na vas!

In zdaj se vaš duh sramuje, da je na voljo vašemu drobovju, in zaradi lastnega sramu hodi tiholazna in lažna pota.

»Zame bi bilo največ, « tako govori vaš zlagani duh sam pri sebi, »gledati življenje brez poželenja, ne pa kakor pes s pobešenim jezikom:

Biti srečen v gledanju z odmrlo voljo, brez grabežljivosti in poželjivosti sebičnosti mrzel in pepelnato siv po vsem telesu, vendar s pijanimi mesečnimi očmi!

Meni bi bilo najljubše«, tako samega sebe zapeljuje zapeljani, »ljubiti zemljo, kakor jo ljubi mesec, in samo z očesom otipavati njeno lepoto.

In to se mi pravi brezmadežno spoznanje vseh stvari, da nič nočem od stvari: razen da smem ležati pred njimi kakor ogledalo s sto očmi.«-

O, vi občutljivi hinavci, vi pohotni! Vam manjka nedolžnosti v poželenju: in zato zdaj obrekujete poželjivost! ${ }^{19}$

Drugi bistveni aspekt »objektivnega človeka« je v tem, da znotraj nove hierarhije, ki se vzpostavlja z naraščanjem himerine moči, »objektivni človek“ postane neposredni antagonist filozofa. Na tem antagonizmu je nekaj izrazito težavnega, tudi težko razumljivega. Antagonizem med filozofom in »objektivnim človekom « je namreč nedvomno oboje: tako resničen in realen kakor tudi lažen - in da bo problem še večji: ta antagonizem nedvomno postane najresničnejši prav na točki, na kateri njegova lažnost kulminira do največje skrajnosti.

Antagonizma namreč ne opišemo pravilno, če preprosto rečemo, da sta filozof in »objektivni človek« tekmeca. Po Nietzscheju to v resnici sploh nista, in za strategijo filozofa $v$ tem boju je bistveno, da na to primerjavo, oziroma sploh na samo primerljivost, nikakor ne pristane.

Prav tako antagonizem napačno predstavimo, če rečemo, da je zaradi vsesplošnega napredka znanosti »objektivni človek« na družbeni lestvici prehitel filozofa in zasenčil njegovo staro slavo. Tudi v tem, navidez neizpodbitnem dejstvu je po Nietzscheju na delu iluzija: kljub vsemu napredku znanosti je realna družbena moč znanstvenika zelo relativna. Še več: tudi tista družbena moč, ki jo znanost ima, je po Nietzscheju skoraj v celoti izposojena od sil, ki so znanosti

19 Friedrich Nietzsche, Tako je govoril Zaratustra, prev. Janko Moder, Slovenska matica, Ljubljana 1999, str. 142. 
zunanje in ki v resnici vladajo nad njo. Družbena moč »objektivnega človeka« ni avtonomna moč njega samega, temveč mu to moč posreduje demokratična morala, da bi z njegovo pomočjo spodkopala avtoriteto bistveno ambicioznejših, agresivnejših sil, kakršni sta filozofija in religija, ki dejansko želita zavladati nad mnenji ljudi, se naseliti vanje. Moč, v imenu katere naj bi znanost presegla filozofa, je torej že v samem izhodišču izpeljana iz njega samega, in sicer kot reakcija nanj in njegovo voljo do narekovanja novih vrednot. Tudi v tem pogledu je torej za filozofa bistveno, da ne nasede videzu »dejstev«, videzu realnosti.

A v čem je torej realnost opisovanega antagonizma? Filozof in »objektivni človek« nista tekmeca v smislu, kdo bo koga prehitel na družbeni lestvici; njun spopad je bistveno smrtonosnejši: v njem gre namreč za spopad, kdo bo zavzel sam položaj filozofa.

Razglas o neodvisnosti znanstvenega človeka, njegova osamosvojitev od filozofije, je ena tenkočutnejših posledic demokratičnega dejanja in nehanja: samopoveličevanje in samopovzdigovanje učenjaka je danes povsod $v$ vsem razcvetu in $\mathrm{v}$ najlepši pomladi - s čimer pa naj še ne bi bilo rečeno, kakor da v tem primeru lastna hvala ljubo diši. »Stran od vseh gospodarjev! - tako hoče šesti čut sodrge tudi tukaj; in potem ko se je znanost $\mathrm{z}$ najsrečnejšim uspehom ubranila teologije, katere »dekla « je bila predolgo, se je zdaj v vsej prevzetnosti in nerazsodnosti odločila, da bo postavila zakone filozofiji in enkrat sama zaigrala "gospodarja« - kaj pravim! - filozofa. ${ }^{20}$

Antagonizem torej kulminira v tem spopadu biblijskih razsežnosti, ${ }^{21} \mathrm{v}$ katerem se filozof in »objektivni človek« spoprimeta za samo mesto filozofa; spopadu, ki preti z nevarnostjo, da bo filozof tako rekoč od znotraj nadomeščen s svojim ponaredkom. In prav ta eskalacija antagonizma je - za razliko od antagonizma samega, v katerem je po Nietzscheju treba videti predvsem konstrukt interesov demokratične morale - dejansko realna: realno jedro antagonizma, prag, prek katerega se ta skonstruirani, navidezni antagonizem pretvarja $v$ realnost, za Nietzscheja namreč predstavlja notranji boj med filozofom in tisto obliko »objektiv-

$20 \quad$ Nietzsche, Onstran dobrega in zla, str. 107.

${ }^{21}$ O biblijski razsežnosti spopada za isto mesto, ki poteka v obliki Antikristove varljive uzurpacije Kristusovega navidez izpraznjenega mesta, glej: Marisa Žele, »Antikrist in izvorna pozaba - varljivec v biblijski ontologiji«, Problemi 9-10, letnik LV, Društvo za teoretsko psihoanalizo, Ljubljana 2017, str. 114-119. 
nega človeka«, ki je v resnici že zdavnaj postala prevladujoča znotraj filozofije in ki jo Nietzsche imenuje »filozofski delavec«. »Vztrajam pri tem, naj se nazadnje že neha zamenjevati filozofske delavce in sploh ljudi znanosti s filozofi - da je ravno tu treba strogo dajati »vsakemu svoje« in ne onim preveč in ne tem preveč premalo. $\ll^{22}$

Poskusimo to, za zdaj samo skicirano topologijo problema, podrobneje razgrniti v vseh njenih dimenzijah:

Nietzsche je ključno besedilo »Mi učenjaki « vpeljal rekoč, da je cilj tega besedila intervencija v tisto, kar imenuje Rangverschiebung v razmerju med znanostjo in filozofijo. Obstoječi slovenski prevod tega pojma se glasi "prerazvrščanje stopenj«; sam bom Rangverschiebung raje prevajal kot »premena v rangiranju«, saj menim, da na ta način precej bolje naglasimo poudarek na hierarhiji, ki je za Nietzscheja v vseh pogledih bistven.

Ne glede na nevarnost, da se moraliziranje tudi tukaj pokaže kot tisto, kar je zmeraj bilo - namreč neomajno montrer ses plaises, po Balzacu - bi želel tvegati in nastopiti proti neprimernemu in škodljivemu prerazvrščanju stopenj [Rangverschiebung], kakršno grozi, da se bo popolnoma neopaženo in kakor z najboljšo vestjo vzpostavilo danes med znanostjo in filozofijo. ${ }^{23}$

Nietzschejevo besedilo torej opravlja tri naloge v enem: interpretira proces neke realne spremembe, vendar pa je cilj te interpretacije nedvomno motiviran z nekim učinkom - cilj te interpretacije je poseči v to, kar interpretira; spremeniti potek spremembe, katero anticipira. Sama interpretacija mora torej nase vzeti to trojno nalogo reprezentacije, anticipacije in posega. ${ }^{24}$

22 Nietzsche, Onstran dobrega in zla, str. 120.

${ }_{23}$ Ibid., str. 107.

24 Vsekakor velja izpostaviti globoko sorodnost med Nietzschejevim posegom v Rangverschiebung in konceptom »intervencije v nepovratno«, ki ga je sicer na podlagi povsem drugačnih filozofskih izhodišč in obravnave povsem drugačnih problemov razvil Tadej Troha. Ujemanje na ravni vseh treh ključnih kategorij filozofskega vrednotenja, se pravi, na ravni hkratnega součinkovanja reprezentacije, anticipacije in posega, se mi zdi še posebej razvidno iz naslednjega odlomka iz Trohovega besedila »Inercija krize«: »Reševanje ekološke krize je že po definiciji intervencija v nepovratne procese, intervencija v procese, ob katerih odpovedo tudi običajni kriteriji uspeha politične intervencije. Prvič, da bi se lahko izognili katastrofi, moramo na eni strani vselej oceniti maksimalno inercijo, ma- 
Nietzschejev tekst je torej že v prvem koraku - na ravni drže, ki jo zavzema ostro zoperstavljen idealu »brezinteresnega spoznanja«. A vprašati se moramo zlasti, na kakšen način je tak poseg interpretacije v neko še kako realno spremembo, kakršno predstavlja premena v rangiranju med znanostjo in filozofijo, sploh mogoč?

Osnovni odgovor smo že nakazali: Rangverschiebung v razmerju med znanostjo in filozofijo je seveda brez vsakega dvoma realen proces, vendar pa pri tem nikakor ne smemo prezreti, da podlago tega procesa tvori operacija videza, ki se biti polasti šele prek neadekvatnosti reakcije, prek katere se filozofija odzove nanjo. Z drugimi besedami, sama Rangverschiebung, premena v rangiranju, je že sama po sebi predvsem neka agresivna interpretacija, ki sicer zagotovo spreminja realnost, vendar pa v svoji podlagi ne sloni na dejstvih, temveč na sposobnosti, da videz dejstev ustvarja. In prav na tej ravni se je mogoče $z$ njo spustiti v odkrit duel in poskusiti presekati dotok videza v realnost, na katerem sloni.

Če smo na ta način določili status Nietzschejevega pristopa, poskusimo zdaj trdneje določiti še položaj, ki ga v razmerju do premene v rangiranju med znanostjo in filozofijo zavzema objektivnost. Položaj objektivnosti je v esencialnem pomenu dvojen. V vzponu objektivnosti je, po Nietzscheju - v vseh njegovih različicah, vključno s filozofskimi razpravami o utemeljitvi objektivnega spoznanja -, treba najprej videti bistveni simptom same Rangverschiebung. Skratka, vzpon veljave objektivnosti je treba najprej dojeti kot reakcijo na tisto 'realno', ki ga naraščanje pomena znanosti v razmerju do filozofije nedvomno proizvede. Po drugi strani pa je objektivnost vseeno tudi več kakor zgolj simptom. Objektivnost sodi tudi v red razlogov, ki so sprožili proces premene $\mathrm{v}$ rangiranju: vendar in to je bistveno - ne v svoji primarni formi, se pravi, kot metodološka podlaga znanstvenega napredka, ki naj bi znanosti zagotavljal čedalje večjo družbeno veljavo, temveč v formi svoje druge metamorfoze, torej kot tista družbena vrednota, ki - v obliki utelešanja afinitete med zavzemanjem nevtralnih gledišč

ksimalni doseg nepovratnosti, prihodnost situacije, do katere lahko pripelje status quo, odsotnost alternativne politične intervencije. Drugič, da bi lahko realno ocenili potencial naše intervencije, moramo najti način izmere minimalne inercije stanja pred intervencijo, izmeriti torej delež prihodnosti, ki ni le okvirno določen, temveč v strogem smislu že zapečaten, radikalno neizbežno determiniran.« Tadej Troha, »Inercija krize«, Filozofski vestnik 37 (3/2016), str. 150-151. 
in formalno enakostjo vseh mnenj - zapečati zavezništvo med demokratično moralo in znanostjo na škodo filozofije.

In natanko sem je treba umestiti osnovni preboj Nietzschejeve interpretativne intervencije. Rangverschiebung se nikoli ne bi mogla realizirati, prestopiti iz videza v bit, če filozofija ne bi postavila napačne diagnoze in zamešala resničnega gonila Rangverschiebung z lažnim; zamešala dveh himerinih glav. Filozofija je potem ko je zaslutila, da na nek način izgublja primat nad znanostjo - postavila napačno diagnozo te spremembe: precenila je realni domet družbene moči znanosti in podcenila, če ne celo v celoti prezrla, skrito zavezništvo med znanstvenim pogonom in demokratično moralo - »nagonom sodrge«, kot temu pravi Nietzsche -, zavezništvo, ki ga v najmočnejšem smislu uteleša prav dvojna, himerična narava objektivnosti. Filozofija je torej najprej storila to napako, da je antagonizem z znanostjo vzela preveč zares, sprejela je to $\mathrm{v}$ resnici neobstoječo tekmo in se je lotila tako, da se je poskusila sama polastiti objektivnosti, v kateri je sicer pravilno dojela gonilo napredka znanosti, a pri tem spregledala, da njen napredek ni tisto, kar znanosti dejansko podeljuje njeno družbeno veljavo. Filozofija je tako postala sama obsedena z objektivnostjo - v njej je začela odkrivati neznane globine, iz nje je na vsak način hotela narediti nekaj neznansko kompleksnega, filozofskega, pripadajočega njej sami, filozofiji -, se na ta način začela čedalje bolj omejevati na epistemologijo, s pomočjo katere naj bi bodisi odkrila fundamente svoje lastne objektivnosti bodisi pojasnila znanstveno objektivnost, se začela zapirati vanjo - in na ta način sistematično usihati. Šele na ta način, torej zaradi njene lastne pretirane fascinacije $\mathrm{z}$ objektivnostjo, na kateri ni po Nietzscheju v resnici nič posebnega - objektivnost je zanj zgolj stroga disciplina, pisana na kožo psihološkega ustroja »objektivnega človeka«; na njej ni nič več in nič manj, kakor (sicer redka) sposobnost "prebrati tekst takšen, kakršen je« -, je filozofija samo sebe izčrpala in privedla do točke, ko je postala dovolj šibka in obenem tudi že dovolj podobna znanosti, da se je znanost dejansko lahko upravičeno in realno povzpela nad njo:

Nasploh, če vzamemo približno, je najbrž predvsem človeško, prečloveško, skratka revščina novejših filozofov samih, najkoreniteje zlomilo spoštovanje do filozofije in odprlo vrata nagonu sodrge. Moramo si vendar priznati, kako zelo našemu sodobnemu svetu pojema celovita samosvojost Heraklita, Platona, Empedokla in kakor se je še reklo vsem tem kraljevskim in sijajnim samotarjem duha; in kako upravičeno se spričo takih predstavnikov filozofije, ki so danes zaradi mode tako 
zgoraj na konju kakor spodaj na psu - v Nemčiji na primer oba berlinska leva, anarhist Eugen Dühring in amalgamist Eduard von Hartmann - kakšen priden človek znanosti sme počutiti boljše vrste ali rodu. Še posebej pogled na zmedene filozofe, ki se imenujejo »filozofi dejanskosti « ali »pozitivisti«, lahko zaseje v dušo mladega, zagnanega učenjaka nevarno nezaupanje: to so vendar v najboljšem primeru sami učenjaki in specialisti, to je mogoče z rokami otipati! - to so vendar vsi skupaj premagani in pod okrilje znanosti nazaj pripeljani, ki so svoj čas nekoč hoteli od sebe več, ne da bi bili upravičeni do tega »več« in njegove odgovornosti in ki zdaj pošteno, jezno, maščevalno v besedi in dejanju predstavljajo nevero $\mathrm{v}$ gosposko nalogo in vladarstvo filozofije. Nazadnje: kako bi tudi moglo biti drugače! Znanost danes cvete in ji je z obraza lepo brati mirno vest, medtem ko to, v kar se je postopoma pogreznila vsa novejša filozofija, budi nezaupanje in nejevoljo, če že ne porog in sočutje. Filozofija, skrčena na »spoznavno teorijo«, je v resnici samo še boječa epohistika in vzdržništvo: filozofija, ki ne more več niti čez prag in si mučno krati pravico do vstopa - to je filozofija v zadnjih zdihljajih, konec, agonija, nekaj kar zbuja sočutje. Kako bi mogla taka filozofija - vladati!25

V celoti gledano, Nietzschejeva intervencija zoper Rangverschiebung torej napreduje v treh smereh in jo je mogoče povzeti v treh tezah:

a) Ne glede na dejstvo, da si je Rangverschiebung, premena v rangiranju odnosa med filozofijo in znanostjo, že utrla pot iz videza v bit, zavzela institucije in sama začela krojiti realnost, je usoda filozofije še vedno v njenih lastnih rokah. Kot posledica toksičnega ugriza najnižje od himerinih glav (tiste, od katere veje zadah po »sodrgi«), se je filozofija zaljubila v drugo himerino glavo (objektivnost kot podlago znanstvenega napredka) in se zaradi posledic ljubezenskega uroka tako zelo priličila tej drugi glavi, da je doživela metamorfozo ter se sama spremenila $v$ tretjo izmed himerinih glav - »objektivnega človeka«. A če filozofijo pripravimo do tega, da se strezni, skratka, če ji pred oči privedemo dejstvo, da je premena $\mathrm{v}$ rangiranju postala realnost zgolj in izključno zaradi njene lastne napačne diagnoze - prepričanja, da premeno poganja napredek znanosti, ne pa politično 'naravno ravnotežje' med zavzemanjem objektivnih, nevtralnih stališč in formalno enakostjo vseh mnenj -, filozofijo iz Himerinega prijema še vedno lahko potegnemo v skoraj neokrnjeni obliki. Res je sicer, da bo Rangverschiebung zlasti na ravni

25 Nietzsche, Onstran dobrega in zla, str. 108-109. 
institucij pustila svoje sledi, toda to je za Nietzscheja minoren problem. Za razliko od znanosti, ki lahko obstaja le v obliki takšne ali drugačne družbene organiziranosti, je kreacija novih vrednot naloga, ki ji celo ustreza stopnja družbene izolacije, določena samota, odmaknjenost od akademskega sveta. Veliko bolj pomembno je, da na ta način - se pravi, s pravilno razlago vlog, ki jih opravljajo posamezne himerine glave - filozof lahko preneha samega sebe tragično zamešavati s svojim ponaredkom, preneha v samem sebi videti podzvrst »objektivnega človeka«, in sami objektivnosti znova odmeri vlogo, kakršna ji pritiče, in sicer: vlogo nedvomno koristnega in nujnega orodja, ki pa vendarle ni nič več kakor to - se pravi orodje filozofije, in ne njen ideal.

b) Antagonizem med filozofijo in znanostjo ni v resnici nič drugega kakor maska in sredstvo - oboje v enem - nekega drugega antagonizma, in sicer antagonizma med filozofijo in demokratično moralo. Prestiž, ki ga sodobna demokratična družba podeljuje znanstvenemu človeku, videz, da je prerasel filozofa, je po Nietzscheju torej v prvi vrsti treba razumeti kot nekakšno predplačilo, ki ga »objektivni človek« prejme na svoj račun v zameno za pripravljenost na igro, da mu znesek, ki ga je prejel, tudi v resnici pripada. Vtisa, da je znanost presegla in prerasla filozofijo, se je treba torej dokončno znebiti, za to pa zadošča že, da si dovolj jasno predočimo, da je ta »objektivni videz« preseganja in preraščanja zgolj sredstvo, s pomočjo katerega je premena v rangiranju ugrabila svojo realno bit, in ne ta realna bit sama.

c) Razlog, da je v »objektivnem človeku« kljub prestižu, ki mu ga sodobna družba podeljuje, treba videti razmeroma šibko silo, je po Nietzscheju v tem, da je družbena moč znanosti vselej postavljena $\mathrm{v}$ odvisnost od drugih tipov moči: »Ne! Ne prihajajte mi z znanostjo, ko iščem naravnega antagonista asketske$\mathrm{mu}$ idealu, ko sprašujem: »kje je nasprotna volja, v kateri se izraža njegov nasprotni ideal? Znanost za to še zdaleč ni dovolj samostojna, ona v vsakem primeru potrebuje neko vrednoto-ideal, vrednote ustvarjajočo moč, v katere službi edino lahko verjame sama vase, - ona sama nikoli ne ustvarja vrednot. Njeno razmerje do asketskega ideala še ni na sebi čisto nič v antagonizmu z asketskim idealom; v glavnem se še celo prej postavlja kot naprej poganjajoča sila njegove notranje izoblikovanosti. ${ }^{26}$ Znanost, ki sama po sebi ni zmožna

26 Friedrich Nietzsche, H genealogiji morale, prev. Janko Moder, Slovenska matica, Ljubljana 1988, str. 336-337. 
ustvarjati vrednot, je torej za Nietzscheja v esencialnem smislu odvisna sila; sila, ki je sploh nezmožna samostojnega antagonizma. Sprva se je naslanjala na filozofijo, prek procesa Rangverschiebung pa je vstopila v zavezništvo z demokratično politiko, znotraj katerega pa je njen položaj postal kvečjemu še šibkejši. Znotraj sodobne demokratične družbe znanost sicer nedvomno predstavlja nekakšno protiutež kaosu mnenjskega pluralizma, vendar pa sama po sebi enostavno nima na voljo instrumentov, da bi neposredno posegala vanj; odvisna je od demokratične politike, in posredno torej od istega mnenjskega pluralizma, katerega naj bi uravnoteževala. Dodeljena ji je vloga nadzornika z zavezanimi rokami. Eden od glavih razlogov, če ne celo glavni razlog Nietzschejevega prepričanja, da filozofija "po zakonitostih reda stopenj« ostaja in bo ostala nad znanostjo, je ravno v tem, da filozofija, v nasprotju s to esencialno odvisnostjo družbene moči znanosti, predstavlja silo, ki dolgoročno, prek ustvarjanja vrednot - torej prek izpolnjevanja svoje lastne notranje filozofske naloge - neodvisno in neposredno deluje tudi kot politična, družbeno-transformativna sila, kateri se ni treba naslanjati na nikogar.

Verjamem, da je skoraj nemogoče, da nam ta Nietzschejeva trojna diagnoza ne bi vzbujala mešanih občutkov. Po eni strani Nietzscheju ni mogoče odreči priznanja, da je v času, ko to sploh še ni bilo tako zelo razvidno, vizionarsko napovedal radikalen prevrat $v$ hierarhiji razmerja med filozofijo in znanostjo. Po drugi strani pa nam - mislim, da je tudi to skoraj povsem neizbežno - Nietzschejeve rešitve, zlasti njegov poudarek na ohranitvi vodilne vloge filozofije, puščajo vtis nekakšnega pobega pred 'realnim' tega tektonskega premika. A dejansko se prav tu odpre vprašanje, ki nam omogoči, da se v proces Rangverschiebung vključimo kot protagonisti.

Dilema je kristalno jasna: je ta naša ocena zares objektivnejša od Nietzschejeve vizije, ali pa je zgolj podana $z$ vrednostnega gledišča »objektivnega človeka«, ki ga je Rangverschiebung vtisnila v naš način razmišljanja?

Nobenega dvoma ni, da je znanost $\mathrm{v}$ času približno sto štiridesetih let, ki nas ločijo od obdobja, ko je Nietzsche postavil svojo diagnozo, opravila izjemen razvoj. A nas dejansko zanima vprašanje kriterija, po katerem je mogoče trditi, da je znanost presegla in prerasla filozofijo. In ta kriterij je - tako v našem, kakor v Nietzschejevem času - v resnici isti: utilitaristični nazor, v skladu s katerim je kategorija družbenega pomena postavljena $\mathrm{v}$ enostaven enačaj s pojmom ne- 
posredne družbene koristi. O tem je bilo seveda napisanega ogromno - izstopa zlasti znamenita Lyotardova študija, ${ }^{27} \mathrm{ki}$ je v veliki meri zasnovana prav na Nietzschejevih izhodiščih. Problem utilitarističnega vrednotenja seveda ni v tem, da bi znanosti pripisoval preveč; problem tega nazora je v tem, da je s svojo prevlado tako rekoč izbrisal tisto, kar dejansko je družbeni smoter filozofije. Med naštevanjem "predsodkov«, zaradi katerih je filozofija v očeh znanosti izgubila ugled, je Nietzsche izpostavil »barvno slepoto utilitarista, ki v filozofiji ne vidi nič drugega kakor vrsto spodletelih sistemov in zapravljivo potratnost, ki nikomur »ne koristi ${ }^{28}$

Ta izbris smotra, družbenega pomena filozofije ima po Nietzscheju svoje korenine v najglobljem antagonizmu zahodne civilizacije. Princip vrednotenja, ki poteka pod krovno vrednoto koristi, skratka, vrednotenje, ki odgovarja na vprašanje, »čemu (nekaj) služi?«, za Nietzscheja predstavlja kvintesenco tistega, kar imenuje »morala sužnjev«: »Morala sužnjev je pravzaprav morala koristnosti. «29 »Morala sužnjev« ni le politična kategorija, temveč je v njej, kot je verjetno najbolje razložil Deleuze, treba razbrati tudi ontološko dimenzijo: "morala sužnjev« označuje »triumf reaktivnih sil«; predstavlja kriterij negativne selekcije, ki vrednost dodeljuje zgolj tistim silam, ki so prek svoje »koristi« podrejene nečemu drugemu; vse druge (aktivne) sile pa zapiše pozabi. ${ }^{30}$

Filozofija že v izhodišču, na ravni svoje biti, pripada diametralno nasprotnemu principu vrednotenja, ki ga Nietzsche imenuje "gosposko«, "aristokratsko« vrednotenje. Nasprotje med obema tipoma vrednotenja morda najbolje izrazi naslednji Nietzschejev zapis: "Bistvo dobre in zdrave aristokracije pa ni v tem, da se počuti kot funkcija (naj bo že kraljevine ali skupnosti), temveč kot njen smisel in najvišje opravičevanje «.31

${ }_{27}$ Prim., Jean-François Lyotard, Postmoderno stanje, Društvo za teoretsko psihoanalizo, Ljubljana 2002, str. 72-93. Prim. tudi Aleš Bunta, »Lyotard: filozofija in vprašanje legitimacije vednosti «, str. 113-149.

28 Nietzsche, Onstran dobrega in zla, str. 108.

29 Ibid., str. 177.

30 Glede povezave med znanostjo in »triumfa reaktivnih sil, glej: Gilles Deleuze, Nietzsche in Filozofija, prev. Aljoša Kravanja, Krtina, Ljubljana 2011, str. 66.

31 Nietzsche, Onstran dobrega in zla, str. 173. 
Tega Nietzschejevega stavka niti približno ne smemo razumeti v smislu, da filozofija sama sebi predstavlja svoj namen - videli smo, da filozofija (vredna tega imena) po Nietzscheju še kako stremi in drvi proti nekemu prelomu, proti nekemu učinku, proti nekemu cilju. Na nek način bi lahko dejali skoraj obratno: filozofija - podobno kot po Nietzscheju velja za vso "višjo kulturo« - se mora doživljati kot najvišji smisel družbe, da bi na ta način sploh lahko pristopila k opravljanju svoje naloge: filozofija mora izhajati iz absolutne samoafirmacije, da bi na ta način lahko prek same sebe in $v$ formi same sebe zarisovala nove horizonte.

\section{Literatura}

Bunta, Aleš, »Lyotard: filozofija in vprašanje legitimacije vednosti«, Problemi 47 (8/2009), str. $113-147$

Deleuze, Gilles, Nietzsche in Filozofija, prev. Aljoša Kravanja, Krtina, Ljubljana 2011

Derrida, Jacques, Ostroge. Nietzschejevi stili, prev. Jana Pavlič, Hyperion, Koper 2010

Heidegger, Martin, Nietzsche Volume III: The Will to Power as Knowledge and as Metaphysics, Harper and Row, San Francisco 1987

- »Nietzschejeve besede 'Bog je mrtev'«, prev. Aleš Košar, Phainomena 9 (31-32/200o), str. $143-187$

Klossowski, Pierre, Nietzsche and the vicious circle, Continuum, London 1997

Lyotard, Jean-François, Postmoderno stanje, prev. Simona P. Grilc, Društvo za teoretsko psihoanalizo, Ljubljana 2002

Nietzsche, Friedrich, Onstran dobrega in zla. H genealogiji morale, prev. Janko Moder, Slovenska matica, Ljubljana 1988

- Volja do moči, prev. Janko Moder, Slovenska matica, Ljubljana 1991

- Tako je govoril Zaratustra, prev. Janko Moder, Slovenska matica, Ljubljana 1999

- Vesela znanost, prev. Janko Moder, Slovenska matica, Ljubljana 2005

- Jenseits von Gut und Böse. Zur Genealogie der Moral. Kritische Studienausgabe Herausgegeben von Giorgio Colli und Mazzino Montinari, de Gruyter, Berlin and New York 1967

Troha, Tadej, »Inercija krize«, Filozofski vestnik 37 (3/2016), str. 141-151

Zupančič, Alenka, »Asketski ideal«, Filozofski vestnik 20 (1/1999), str. 57-72

Žele, Marisa, »Antikrist in izvorna pozaba - varljivec v biblijski ontologiji«, Problemi 55 (9-10/2017), str. 109-135 